IZA DP No. 6932

Worker Cooperatives and Democratic Governance

John Pencavel

October 2012 


\title{
Worker Cooperatives and Democratic Governance
}

\author{
John Pencavel \\ Stanford University, \\ SIEPR and IZA
}

\section{Discussion Paper No. 6932 \\ October 2012}

\author{
IZA \\ P.O. Box 7240 \\ 53072 Bonn \\ Germany \\ Phone: +49-228-3894-0 \\ Fax: +49-228-3894-180 \\ E-mail: iza@iza.org
}

Any opinions expressed here are those of the author(s) and not those of IZA. Research published in this series may include views on policy, but the institute itself takes no institutional policy positions. The IZA research network is committed to the IZA Guiding Principles of Research Integrity.

The Institute for the Study of Labor (IZA) in Bonn is a local and virtual international research center and a place of communication between science, politics and business. IZA is an independent nonprofit organization supported by Deutsche Post Foundation. The center is associated with the University of Bonn and offers a stimulating research environment through its international network, workshops and conferences, data service, project support, research visits and doctoral program. IZA engages in (i) original and internationally competitive research in all fields of labor economics, (ii) development of policy concepts, and (iii) dissemination of research results and concepts to the interested public.

IZA Discussion Papers often represent preliminary work and are circulated to encourage discussion. Citation of such a paper should account for its provisional character. A revised version may be available directly from the author. 
IZA Discussion Paper No. 6932

October 2012

\section{ABSTRACT}

\section{Worker Cooperatives and Democratic Governance*}

A worker co-operative is a firm that is owned and managed by those who work in it. This paper provides a selective review of research in economics on worker cooperatives. It concentrates on the volatility of earnings and employment in the co-ops compared with conventional capitalist firms; on the long-term viability of co-ops; on the relative productive efficiency of co-ops; and on problems of democratic governance within co-ops. Using modern empirical methods applied to large numbers of observations, recent research has substantially enhanced our understanding of worker co-ops.

JEL Classification: J54

Keywords: $\quad$ worker cooperatives, comparative efficiency, viability

Corresponding author:

John Pencavel

Department of Economics

Stanford University

Stanford, CA 94305-6072

USA

E-mail: pencavel@stanford.edu

* Prepared for the Handbook of Economic Organization edited by Anna Grandori. 


\section{WORKER COOPERATIVES AND DEMOCRATIC GOVERNANCE}

\section{John Pencavel ${ }^{*}$}

\section{Introduction}

When presented with shocks to their economic environments, do firms behave differently when workers control decisions in the organization in which they work? There is a vast empirical literature addressing this question when the workers are organized in a body such as a union and when the union bargains with the owners or with the owners' agents in a conventional firm. In these circumstances, the firm's outcomes reflect the mixed and possibly conflicting objectives and constraints of the owners, the managers, and the production workers (or their representatives). The impact of the workers' preferences and constraints on the outcomes of firms are likely to be most salient when the workers own and manage the firm in which they work. The behavior of such firms, worker cooperatives, is the subject of this essay.

Some argue that the prevalence of the capital-owned and capital-managed firm in market economies is testament to the superiority of this form of organization, the survival and proliferation of the fittest. ${ }^{1}$ Certainly, the success and ubiquity of the capitalist firm as an economic organization calls for explanation. Yet the enduring attraction of worker-owned and worker-

\footnotetext{
* Comments on an earlier version of this paper by Ran Abramitzky, Anna Grandori, Derek Jones, and Virginie Pérotin are acknowledged with thanks.

${ }^{1}$ A well-written summary and evaluation of the arguments for the dominance of the capitalist enterprise is Dow and Putterman (1999).
} 
managed firms also asks for an understanding. Such organizations, where permitted and not discouraged or impeded, are found all over the world and some have demonstrated an ability to survive inhospitable environments. Indeed, worker co-ops are common in certain professions (such as accounting, law, medicine, investment banking), ${ }^{2}$ in exchanges for stocks and securities including futures, and in particular types of jobs (taxis, trucking).

A careful study of worker cooperative organizations reveals considerable variety in their capital ownership arrangements. Most palpably, there are co-ops in which the workers use their own savings to provide the organization's capital and in which labor incomes are not separated from capital incomes. There are co-ops in which workers borrow financial capital from financial intermediaries and in which interest payments on these borrowed funds constitute a regular expense. Thus "the" worker co-op is something of a fiction. ${ }^{3}$ However, a key feature of this type of enterprise is that those who work in the firm hold two classes of rights: one right is ownership that includes the right to enjoy any positive residual of gross revenues over costs and the right to exchange this entitlement to another individual; the second right is that of making crucial workplace decisions, decisions that are associated with the firm's supervisors or controllers or directors. In short, the worker co-op combines worker ownership and worker management.

One or other of these two rights are often found in other firms in modern market

${ }^{2}$ Levin and Tadelis (2005) account for the frequency of co-ops in many professions in terms of information asymmetries. The net revenue-sharing feature of these partnerships prompts them to be unusually sensitive to the quality of the people with whom the profits will be shared. They are better able to identify high quality individuals than consumers who, in turn, come to recognize the superior product of the co-op organization.

${ }^{3}$ This is consistent with Lamoreaux'(1998) historical analysis of corporations and partnerships which stresses the continuum of arrangements rather than distinct and discrete categories of organizations. 
economies. ${ }^{4}$ For instance, through Employee Stock Ownership Plans (ESOPs), many workers in the U.S. have become part owners of the firms in which they work so the dimension of worker ownership in worker co-ops is found, at least in part, in many other enterprises. ${ }^{3}$ The right to contribute to decision-making within an organization also exists in firms where workers sit on employee-involvement committees or health and safety panels or union-management work bodies. The operation of ESOPs and of employee participatory programs has been a vigorous area of research in its own right and the behavior of worker co-ops may be relevant to an assessment of the effectiveness of these other ventures too.

Given existing authoritative surveys of research on worker co-ops, ${ }^{4}$ this paper concentrates on recent research and on the scholarship of a few key issues. These issues concern the volatility of employment and earnings, the long-term viability of co-ops, the comparative production efficiency of co-ops, and problems of democratic governance within co-ops.

\footnotetext{
${ }^{4}$ Thus a recent volume introduces itself with the following claim: "Almost half of American privatesector employees participate in 'shared capitalism' - employment relations where the pay or wealth of workers is directly tied to workplace or firm performance. In many of these firms employees also participate in employee involvement committees or workplace teams that help management make decisions regarding the economic activities of the firm.” (Kruse, Freeman, and Blasi, (2010) p.1)

${ }^{3}$ Because workers tend to fear the employment consequences of new owners, firms threatened by take-overs have sometimes placed more of the firm's stock in the accounts of employees through ESOPs to repel predators. Examples have been provided by United Airlines and Weirton Steel. In these cases, the firm's shares are placed in a trust for employees who can access them upon retiring or upon leaving the firm. Then the firm often buys back the shares to retain ownership among the employees. Corresponding information for Europe is found in Pérotin and Robinson (2003) and for Japan in Jones and Kato (1995).

${ }^{4}$ See especially Dow (2003) and Bonin, Jones, and Putterman (1993).
} 


\section{Models}

Our understanding of the behavior of the conventional capitalist firm has been enriched by basic purposive models that strip particular and idiosyncratic elements from the firm’s activities and that concentrate on generalizable and fundamental aspects. The principal workhorse among these purposive models has been that which ascribes to the capitalist organization the object of profit maximization: the firm's responses to changes in its economic environment are not serendipitous but are best understood as if the firm's decision-makers were deliberately and consciously pursuing the goal of maximizing net revenues or profits. There have been constructive modifications of profit maximization to take up issues such as discrimination, managerial discretionary behavior, and other factors, but these have been understood as refinements of a model to deal with special circumstances and concerns and not as overturing wholesale the central characterization of net revenue maximization. What is the corresponding model to describe the worker co-op’s responses to changes in its economic environment?

This question was taken up by Ben Ward in a seminal article in 1958. He proposed that a worker co-op’s behavior is best understood as deriving from the maximization of net revenues per co-op member where wage payments to members are not counted in the computation of net revenues. I label this the income maximization hypothesis. What does it imply?

In the simplest of characterizations, it assumes a congruence of members and workers: all co-op members are workers in the co-op and all workers are members of the co-op. Let $E$ denote the co-op's employment which, in turn, equals the co-op’s membership. By virtue of being an owner and by virtue of the overarching principle of equal treatment, each member receives an equal fraction of total net revenues. The co-op employs a second input in production - call it $M$ for 
raw materials. We assume capital is fixed at a level set by past decisions. The co-op has incurred debts on its loans and its regular payments on these loans are $C$. It operates in a product market environment in which its output (the level of which is given by $X$ ) is sold at an exogenous price of $p$ per unit. Its raw materials are purchased at an exogenous price $r$. A smooth, continuous, strictly quasi-concave production function $X=f(E, M)$ regulates the transformation of inputs, $E$ and $M$, into output $X$. The production function has the property that, for any input prices, the co-op's average cost curve is U-shaped with respect to output. ${ }^{5}$

The co-op's maximand is $D$ defined as

$$
D=E^{-1}(p X-r M-C)
$$

which is sometimes named the dividend rate. The variable inputs, $E$ and $M$, are selected such that $D$ is maximized given the fixed price environment and given the production function. The relationship between each endogenous variable and all predetermined variables are embodied in the following equations:

$$
\begin{aligned}
& E=g_{1}(p, r, C) \\
& M=g_{2}(p, r, C)
\end{aligned}
$$

and, by substituting these in the production function, the co-op's output supply function is derived:

$$
X=g_{3}(p, r, C)
$$

Each of these functions is homogeneous of degree zero in $p, r$, and $C$. An increase in fixed costs, $\mathrm{C}$, can be shown to induce an increase in employment as the co-op distributes these higher fixed costs over more workers, but otherwise these three $g(\bullet)$ equations are devoid of unambiguous sign

\footnotetext{
${ }^{5}$ This assumption guarantees satisfaction of second-order conditions and is discussed in Estrin (1982) and Ireland and Law (1982, pp. 27-30, 182-85).
} 
implications except for those listed below. ${ }^{6}$ Substituting these three equations into the maximand $D$ yields the maximized value of $D$, call it $D^{*}$ :

$$
D^{*}=g_{4}(p, r, C)
$$

The maximum value function (1) is homogeneous of degree one in $p, r$, and $C$. It is nondecreasing in $p$ and nonincreasing each in $r$ and $C$. The envelope theorem implies

$$
\frac{\partial D^{*}}{\partial p}=\frac{X}{E} ; \frac{\partial D^{*}}{\partial r}=-\frac{M}{E} ; \frac{\partial D^{*}}{\partial C}=-\frac{1}{E}
$$

The convexity of $D^{*}$ implies

$$
\frac{\partial^{2} D^{*}}{\partial p^{2}}>0 \Rightarrow \frac{\partial(X / E)}{\partial p}>0
$$

$$
\frac{\partial^{2} D^{*}}{\partial r^{2}}>0 \Rightarrow \frac{\partial(M / E)}{\partial r}<0
$$

$$
\frac{\partial^{2} D^{*}}{\partial C^{2}}>0 \Rightarrow \frac{\partial E}{\partial C}>0
$$

${ }^{6}$ This means the effect of an increase in $p$ has ambiguous implications for the sign of changes in $X$. When labor is the only input, a higher output price induces a fall in employment which, in turn, is associated with a fall in output, a comparative static result that has absorbed a remarkable amount of interest. In the general case, however, the sign of the output-price relationship (the incomemaximizing co-op’s output supply function) cannot be signed unambiguously, as Ward noted. 
Increases in $p$ and $r$ induce changes in output-labor and materials-labor ratios and, as has already been noted, increases in fixed costs increase employment. By Young's Theorem (the irrelevance of the order of differentiation), there is a symmetry condition:

$$
\frac{\partial\left(\partial D^{*} / \partial p\right)}{\partial r}=\frac{\partial\left(\partial D^{*} / \partial r\right)}{\partial p} \Rightarrow \frac{\partial(X / E)}{\partial r}=-\frac{\partial(M / E)}{\partial p}
$$

These homogeneity, symmetry, and sign implications were confronted with panel data on worker cooperatives in the Washington state plywood industry and, by conventional statistical criteria, these implications could not be rejected. ${ }^{7}$

An especially attractive feature of the study of the plywood co-ops in the Pacific North-West is that there were a number of conventionally organized capitalist mills operating there too. Each of the mills (conventional and co-ops) was too small in relation to aggregate output to be anything but price-takers with respect to the purchase of their input of timber and the sale of their output of plywood. Hence we have the opportunity of observing how the two types of mills responded to the large fluctuations in the prices of timber inputs and the prices of plywood. ${ }^{8}$

There were marked differences between the two types of organizations in their

${ }^{7}$ See Pencavel and Craig (1994). Information on $C$, fixed costs, was lacking in these data. However, in some specifications, the equations were fitted allowing for fixed effects for each co-op. The estimates of these co-op fixed effects may be interpreted as holding constant the effects of differences among these plywood mills in their fixed costs.

${ }^{8}$ These prices are, indeed, volatile and the prices of logs reached remarkably high levels in the early 1980s. This brought many purchasers of logs (who often contracted on futures markets) to the brink of bankruptcy. Rescue came in the form of the Timber Contract Buyout Act of 1984 in which the Federal Government took over some debts of the timber buyers. See Mattey (1990). 
responses. When plywood output prices dropped in a recession, the conventional mills responded by substantially reducing their employment and their hours per worker whereas the co-ops changed their labor input little and cut their hourly wages: the elasticity of worker-hours with respect to real plywood prices was $1.100(0.205)$ in the conventional firms while it was $0.096(0.131)$ in the co-ops; the elasticity of real hourly wages with respect to real plywood prices was $0.153(0.151)$ in the conventional firms and $0.978(0.160)$ in the co-ops. ${ }^{9}$

In answer to the question that opened this paper, these results suggest the following hypothesis: an important difference between the prototype capitalist firm and the co-op is that, in response to shocks in its environment, the capitalist firm adjusts quantities - employment, hours, other inputs, and output - while the co-op adjusts earnings per worker. In these plywood co-ops, the definition of earnings per worker includes any periodic dividends to members based on the mill's net revenues in excess of payments to reserves.

Qualitatively, these findings were replicated in a study of very many Italian enterprises $^{10}$ : in response to product market shocks, conventional capitalist firms adjusted employment much more than Italian co-operatives which were more inclined to adjust wages to these shocks. With respect to the income-maximizing model above, there was no persuasive evidence in these Italian co-ops that employment was a negative function of fixed costs (as measured by long-term debt payments) although wages paid in the co-ops tended to be negatively related to fixed costs (as implied by equation (2) above).

\footnotetext{
${ }^{9}$ These values are from the top two panels of Table 4 of Pencavel and Craig (1994). The numbers in parentheses are estimated standard errors.

${ }^{10}$ See Pencavel, Pistaferri, and Schivardi, (2006).
} 
An analysis resembling the aforementioned Italian study was undertaken with Uruguayan firms. ${ }^{11}$ The monthly panel data compiled by Burdín and Dean embrace the entire population of Uruguayan worker co-ops and conventional firms in 31 sectors from April 1996 to December 2005. They estimate annual first-difference equations for wages and employment allowing for responses to changes in predetermined variables to differ between co-op firms and conventional capitalist firms. Indeed, the wages paid to workers in the Uruguayan co-ops were more responsive to exogenous variations in its economic environment than the wages paid to workers in capitalist firms. Furthermore, the response of employment to output price shocks was estimated to be noticeably larger in capitalist firms than in worker co-ops.

This class of research has broadly been supportive of Ward's income maximization hypothesis. This may surprise many supporters and members of worker co-ops who do not view the co-op as simply a monetary venture and who extol the participatory dimension of worker co-ops. Expressed differently, whereas the owners of the capitalist firm will claim that consumers' wants are placed at the center of its mission, members of the co-op place the well-being of the workers at the core of its ideals. For the typical capitalist enterprise, the well-being of its workers is achieved as a by-product of the firm's activities; for the co-op the well-being of its member-workers is a distinct and categorical goal. The master-servant relation that predates the employer-employee association in the capitalist firm is replaced in the co-op by one of self-employment and the democratic determination of issues. Ward's income maximization hypothesis does not recognize this transformation of the workplace and yet the model still appears to perform creditably.

\footnotetext{
${ }^{11}$ See Burdín and Dean (2009).
} 


\section{Degeneration}

An enduring concern among proponents of worker co-ops has been that the co-op would evolve over time in such a way as to lose its distinctive participatory and democratic character. The process has been called "degeneration" and it is often associated with the writings of Beatrice Potter and Sidney Webb who drew these inferences from the study of British worker coops. ${ }^{12}$ Different explanations for degeneration have been offered. For example, some have seen in worker co-ops the operation of Robert Michels' "iron law of oligarchy" in democratic organizations: a tendency for an elite within the co-op to assume a growing and commanding role that results in the effective capture of the enterprise.

Another argument turns on the nature of the co-op's financing. In meeting the enterprise's capital requirements, some advocates of the co-op organization have expressed a preference for external financing over self-financing. Drawing upon the experience of co-ops, Vanek (1977) felt that self-financing inclines the co-op's founders to regard themselves as the firm's aristocrats and subsequent members tend to be viewed as subordinate, something that undermines cooperation and work effort. ${ }^{13}$ Self-financing is said to encourage a focus on the monetary returns

${ }^{12}$ See Potter (1891, especially Chapter V) and Sidney and Beatrice Webb (1921, especially pp. 47287). Of course, Beatrice Potter (Webb) (1858-1943) should not be confused with Beatrix Potter (1866-1943). Different versions of the degeneration hypothesis are investigated in Cornforth (1995).

${ }^{13}$ Ellerman (1990) has expressed a similar concern with self-financing. His argument is that ownership of capital by the workers is no more to be encouraged than capital ownership by conventional capitalists. He writes, "The villain of capitalist production is not private property or free markets (far from it), but the whole legal relationship of renting, hiring, or employing human beings. It was the employment relation that allowed some other party to hire the workers so that together with the ownership of other inputs, that party would be the residual claimant..... Only the democratic firm - where the workers are jointly self-employed - is a genuine alternative to private or public employment.” (1990, pp. 208-9) 
of the enterprise whereas external financing is conducive to the broader vision of the co-op in which the community's well-being figures in its concerns. As workers retire from the co-op, the internallyfinanced co-op will tend to replace them with capital and a privileged class emerges.

Perhaps the most common expression of the degeneration argument has been that the owners of a financially successful co-op would be induced to capitalize (pun intended!) on their venture and hire non-member employees in place of departing member-workers. Over time, the organization would diverge from the principle that all workers are members and all members are workers; an increasing fraction of workers would be non-member employees. Eventually the firm would be indistinguishable from many conventional firms with ownership concentrated in the hands of a few and with key decisions taken by a small number of remaining owners. ${ }^{14}$

This worry is by no means fanciful. Thus the Olympia Veneer Company, the inspiration for the various plywood co-ops in the Pacific North-West, started operations in 1921 with 125 member-workers and, after initial difficulties, it prospered for many years. As founding member-workers left the mill, the co-op bought back the shares of the departing members and hired non-member workers in their place. By 1952, there were fewer than fifty working members and in 1954 the company was sold to the United States Plywood Corporation at prices that gave the remaining members a handsome return. The exemplar of the successful plywood worker co-op had “degenerated" into a capitalist firm. ${ }^{15}$

Even the group of enterprises long esteemed by the proponents of worker ownership -

\footnotetext{
${ }^{14}$ Various evolutionary paths taken by worker co-ops are described by Ben-Ner (1988).

15 This process of “degeneration” for the co-op resembles a tontine in which members purchase a share in a fund that pays out an annuity whose value increases as a member leaves or dies. This process continues until the final surviving member or members receive the entire fund.
} 
Mondragon - has exhibited signs of such degeneration. Thus, at “the average co-op”, non-member workers constituted ten percent in 1990 and seventy percent in 2007 of Mondragon’s total work force. Among the industrial group of co-ops at Mondragon, non-member workers reached 29 percent of total employment in 2000, but measures to address this dilution of the co-op caused this to decline to 12 percent by $2008 .{ }^{16}$ The Israeli kibbutzim provide another example: their contraction in recent decades has been traced to several factors, one of which has been the increasing use of hired labor. ${ }^{17}$

The "pure" co-op involving the complete congruence of workers and members is not common; many co-ops hire non-member workers. For instance, in those professions in which the organization is owned by the participating "partners", ownership is generally restricted to the practicing attorneys or doctors or accountants; their support staff are usually employees. The income-maximizing model of the worker co-op can easily accommodate hired employees. Indeed, this model implies that, when non-member workers do work that is similar to or substitutable for the work performed by member-workers, an improvement in the co-op's product market will lead to an increase in the employment of non-member employees and a decrease in member-workers.

By contrast, when the work done by the non-member employees is complementary with that undertaken by the member-workers, this replacement of member-workers by non-member

${ }^{16}$ The information in this paragraph is drawn from Arando, Freundlich, Gago, Jones, and Kato (2011). In Mondragon's case, part of the reason for the growth in the employment of non-members has been that Mondragon has opened capitalist enterprises and joint ventures in Spain and overseas. However, there has been a growth in employees within the co-ops also.

${ }^{17}$ See Satt (2007). More economic analysis on the evolution of the kibbutzim is found in Abramitzky (2010). 
employees may not occur. ${ }^{18}$ Hence, in a growing product market, the process of degeneration (an increase in the employment of employees relative to worker-members) is more likely where employees and worker-members do the same or similar work; degeneration is less likely when hired workers and worker-members are complements and do dissimilar work. This is a testable prediction.

In the Uruguayan co-ops, Burdín and Dean (2009) report no meaningful statistical association between changes in output prices and changes in the employment of hired workers as a fraction of all workers. The authors indicate that hired workers often perform functions (such as various managerial activities) distinct from those performed by member workers so the absence of degeneration in these co-ops is consistent with the argument in the previous paragraph. Furthermore, in Uruguay, co-ops face the loss of tax benefits if hired workers pass a certain threshold and this further discourages their employment in co-ops. ${ }^{19}$

The concern about degeneration relates to the evolution over time of the employment structure of the co-op. A different issue pertains to differences across co-ops in the membership-to-

\footnotetext{
${ }^{18}$ It is straightforward to demonstrate this. Suppose, in terms of the notation in Section II, that nonmember employees are given by $M$ and each is paid a wage of $r$. Suppose an increase in $p$ signals an improvement in the co-op's product environment. What does this model imply for $\partial M / \partial p$ and for $\partial E / \partial p$ ? The answer turns on how the marginal product of member-workers is affected by an increase in non-member workers. In other words, it turns on the sign of $\left(\partial^{2} X\right) /((\partial E)(\partial M))$. If $\left(\partial^{2} X\right) /((\partial E)(\partial M))$ is negative, hired employees do work similar to and substitutable for that of member-owners in which case a higher product price (indicating a more favorable product market) induces more employment of hired workers and a lower level of member-worker employment:

$\partial M / \partial p>0$ and $\partial E / \partial p<0$. If the work done by non-member workers is different from and complementary with that of member-workers so $\left(\partial^{2} X\right) /(\partial E)(\partial M)$ is positive, the marginal product of member-workers rises with the employment of more non-member workers. In this case, the signs of $\partial M / \partial p$ and of $\partial E / \partial p$ are ambiguous.

${ }^{19}$ In a subsequent analysis of Uruguayan firms, Burdin (2012) uses longitudinal observations on firms over twelve years and finds that the rate at which co-ops close is lower than the corresponding rates for capitalist enterprises.
} 
employment ratio at the same stage of the life cycle of co-ops. Such differences will be associated, inter alia, with the nature of the skills of the workers. Given the investments they have sunk into the employment relationship with the current co-op, workers with firm-specific skills are more likely to be members of the co-op. By contrast, workers with general human capital have transferable skills that provide job opportunities at other firms and this reduces these workers' dependence on the fortunes of the firm with whom they are currently employed. Such workers are less likely to be co-op members. Does this help to explain why the attorneys in law firms are often members while the para-legals and support staff are employees? ${ }^{20}$

In short, there is a good deal of evidence to support the notion that worker co-ops are apt to evolve over time into non-cooperative organizations. The complicated question is whether this testifies to their success or is a deficiency. Conventional firms often go through transformations that change their organizational form and yet the changes are usually not identified as some sort of inherent failure of the capital-owned enterprise.

\section{Comparative Production Efficiency of Worker Co-ops}

The models of the profit-maximizing capitalist firm and the income maximizing coop are silent about the internal operations of firms. Yet important claims have been made about the internal activities of the worker co-op compared with the conventional firm. A number of these claims make directly opposing assertions.

For instance, in the co-op, the equal division of net revenues among many worker-

\footnotetext{
${ }^{20}$ A recent report described the development at "the nation's biggest law firms" of "a second tier of workers" who do the same work as traditional legal associates but at half the pay. These "career" or "permanent” associates “will never make partner” status (Rampell(2011)).
} 
members is said to provide weak work incentives. ${ }^{21}$ With a manager whose job lasts only so long as the worker-owners being supervised approve of his oversight, it is argued that the co-op membership is prone to excessive malingering. The co-op workers become shirkers. Others claim that the capitalist firm creates an adversarial "us versus them” mentality as supervisors try to extract more effort out of workers who see no benefit to them from working harder. In other words, different work incentives are identified in the two types of firms and completely opposite claims are made about work effort.

Similarly, opposing claims have been made regarding plant, machinery, and raw materials. In their efforts to maintain employment for their members, co-ops are said to be slow and reluctant to adopt advances in labor-saving equipment and they cling to outdated technology and to inadequate capital. In other words, worker co-ops are alleged to underinvest in physical capital. On the other hand, workers in capitalist enterprises do not own the machines they work with nor the plant they occupy and they see little reason to care for the capital with which they work. Supervisors in capitalist firms need to be alert for maltreatment of plant and equipment by workers. This induces greater use of supervisors in capitalist firms who are also told to watch for theft and sabotage. Similar to these arguments about plant and machinery, suggestions have been made that worker-members in co-ops are less wasteful and more careful with raw materials in the value added process. $^{22}$

\footnotetext{
${ }^{21}$ Some of the literature on the productivity effects of profit-sharing in conventional firms is reviewed in Bloom and Van Reenan (2010).

${ }^{22}$ For instance, Dahl (1957, p. 33) observed of the plywood co-ops of the Pacific Northwest that they "....try to get the maximum recovery out of the logs which is a very important factor [in affecting productivity].”
} 
These and other arguments are hypothesizing, first, that, faced with the same prices, capitalist firms and co-ops will select different levels of inputs to produce output. Second, these arguments maintain that, at the same levels of measured inputs, one type of firm will produce more output than the other. These issues have been taken up by researchers in a number of papers who have used information on inputs and outputs to determine whether factor proportions are different in the two types of firms and whether one type of firm extracts more output from its measured inputs than the other type of firm. There have been important differences in these researchers' methods and specifications.

The claims above are not assertions about neutral differences in the firms' production functions. By neutral, I mean production functions that differ only by an intercept and that leave marginal products (or output-input elasticities) unaltered. The arguments about work effort are focused on the effectiveness of labor as an input with the suggestion that the measured workhours of one type of firm correspond to a greater level of effective labor input than that of the other type of firm. The arguments about plant, machinery, and raw materials are conjecturing that typical measures of capital stock and the use of raw materials may miss the different vintages or the different depreciation and wastage rates in the two types of firms.

Investigation of these claims requires fitting production functions separately to worker co-ops and to conventional firms, not by fitting a common production function to both types of firms save for an intercept shift term distinguishing one type of firm from the other. Hence the research most relevant are those investigations that permit the entire production functions for co-ops 
and capitalist firms to differ. ${ }^{23}$ Perhaps the ideal set of observations to pursue these issues is a data set of inputs and outputs of the same firms or plants, some conventional or capitalist firms and others worker co-ops, in a given industry over time. To address the issues raised, a production function is envisaged for the set of input-output observations on the co-ops and a production function is envisaged to describe the input-output patterns for the capitalist firms. ${ }^{24}$

Before turning to this literature, we pause to consider whether observations on inputs

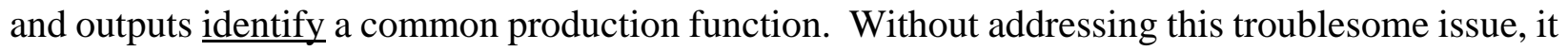
is unclear what the scatter of input-output observations describe. Consider a group of worker co-ops in an industry and suppose each co-op has the same goal as the others. Perhaps this goal is the maximization of net revenues per member-worker. At a given moment, suppose all the co-ops face the same prices for inputs and output. They operate in the same industry and, if a common production function is assumed for these co-ops and if the goal of each firm is the same as that of every other firm, why is each co-op not producing the same level of output with the same levels of inputs as all the other co-ops at that time? From where does the variation in inputs and outputs derive that allows us to fit a "line" to these inputs and outputs at a given moment and to call this a production function?

The same issue arises in the identification of the production function for the capitalist firms in the industry provided each capitalist firm has the same goal such as profit maximization.

${ }^{23}$ This is not a new argument. For instance, the same conclusion was reached by some who have studied the consequences of profit-sharing schemes on various aspects of the performance of firms (e.g., Cable and Wilson (1989)).

${ }^{24}$ Although the analysis of input and output data on coops only may help to answer some questions about the internal organization of co-ops, such data will not aid in addressing the topic in this section, the comparative production efficiency of worker co-ops. 
If input and output prices vary over time, this will generate variations in inputs and outputs over time, but some other source of variation is needed to generate differences in inputs and outputs at a given moment.

One response to this identification problem is to recognize that measured inputs at a given moment diverge from the "true" inputs. Consider the input of labor which is commonly measured by the number of workers or by the number of worker-hours. Neither of these usual ways to measure labor input accounts for variations in work effort or in diligence or in cooperativeness or in other attributes associated with labor as an input to the production process. Similar mismeasurement applies to conventional indicators of raw materials, of machines, and of plant. In fact, convenient simplifying assumptions about the nature of the relationship between the "true" values of the inputs and the "measured" values of the inputs may allow the recovery of the common production function. To show this, suppose the input-output relations of all worker co-ops in an industry over time have a Cobb-Douglas production function of the following sort:

$$
X_{i t}=\exp \left(A_{i}\right) \cdot\left(L^{T}{ }_{i t}\right)^{\alpha} \cdot\left(K^{T}{ }_{i t}\right)^{\beta} \cdot \exp \left(u_{i t}\right)
$$

where the subscript $i$ denotes each co-op and $t$ denotes each period of observation, say, a year. The particular results that follow do not generalize to all other forms of production functions. ${ }^{25} \mathrm{My}$ purpose here is to illustrate some general issues with the most popular of specifications for the

\footnotetext{
${ }^{25}$ Indeed, if the production function is the translog (transcendental logarithmic or a second-order Taylor series expansion in the logarithms of inputs and outputs), the reasoning that follows in the text will not parse so conveniently into measured inputs and firm and time-specific components. Instead, there will be interactions between the measured inputs and the error components.
} 
production function. Particular results depend on production function specifications.

The error-free labor and capital inputs in co-op $i$ at time $t$ are $L^{T}{ }_{i t}$ and $K^{T}{ }_{i t}$ respectively and they are not observed. The superscript $T$ denotes "true”. The multiplicative equation error term is $u_{i t}$ and it stands for latent shocks to output out of the control of the co-op. Examples of such shocks are the weather or economy-wide disturbances linked to the state of the business cycle and macroeconomic public policy. Each co-op in the industry is assumed to have the same elasticity of output with respect to the true labor input $(\alpha)$ and the same elasticity of output with respect to the true capital input $(\beta)$, but among the co-ops there are neutral productivity differences $A_{i}$ that may be related to the production experience (learning-by-doing) of the plant or to its location. Differences in $A$ across co-ops implies that, even at the same input and output prices, different coops will produce different outputs from given measured inputs.

Assume, conveniently, that the "true" inputs are proportional to the measured inputs, $L_{i t}$ and $K_{i t}$ as follows:

$$
L_{i t}^{T}=\left(\lambda^{L}{ }_{i t}\right) L_{i t} \quad K_{i t}^{T}=\left(\lambda^{K}{ }_{i t}\right) K_{i t}
$$

where the factors of proportionality $\lambda^{L}{ }_{i t}$ and $\lambda^{K}{ }_{i t}$ are not constants but vary across firms and over time. Equations (7) embody the assumptions that the true-to-measured input ratios are systematically greater in one co-op than in another and that the true-to-measured input ratios are higher in some years for all co-ops than in other years. Differences in $\lambda^{L}$ and $\lambda^{K}$ across firms and over time cause different co-ops to use different levels of measured inputs to produce different levels of outputs. Substituting these expressions (7) in equation (6) and taking logarithms 


$$
\ln \left(X_{i t}\right)=A_{i}+\alpha \ln L_{i t}+\beta \ln K_{i t}+\alpha \ln \lambda^{L}{ }_{i t}+\beta \ln \lambda^{K}{ }_{i t}+u_{i t} .
$$

Suppose differences and movements in $A_{i}, \ln \lambda^{L}{ }_{i t}$, and $\ln \lambda^{K}{ }_{i t}$ may be characterized by firm (or plant) effects $\mu_{i}$ and time effects $\eta_{t}$ and an "error-components" model results in which measured outputs are related to measured inputs as

$$
\ln \left(X_{i t}\right)=\mu_{i}+\eta_{t}+\alpha \ln L_{i t}+\beta \ln K_{i t}+u_{i t} .
$$

Alternative methods are available to estimate the parameters of this equation depending upon assumptions about the distributions of $\mu_{i}$ and $\eta_{t}$. If $\mu_{i}$ and $\eta_{t}$ are random components and distributed independently of the inputs $\ln L_{i t}$ and $\ln K_{i t}$, a generalized least-squares estimator is consistent. However, this conditional independence is unlikely and the components $\mu_{i}$ and $\eta_{t}$ are likely to be correlated with the inputs. On the other hand, if $\mu_{i}$ and $\eta_{t}$ may be treated as parameters, then a fixed effects estimator is often applied. Nevertheless, the inputs may not be independent of $u_{i t}$ : for instance, if $u_{i t}$ embodies the effects of the weather or business cycle influences on output, then these effects are likely to be correlated with $\ln L_{i t}$ and $\ln K_{i t}$. If appropriate instrumental variables are available (perhaps input and output prices), estimation by instrumental variables needs to be considered. ${ }^{26}$

This general approach was pursued by Craig and Pencavel (1995) in a study of the

${ }^{26}$ These issues harken back to a vigorous literature several decades ago. See, for example, Hoch (1962), Mundlak (1963), and Nerlove (1971). There is, of course, an active contemporaneous literature on these issues. For instance, see Blundell and Bond (2000) and MaCurdy (2007). 
relative productive efficiency of worker co-ops and capitalist enterprises in the Pacific Northwest plywood industry. ${ }^{27}$ Among those firms producing approximately the same quantity of output, the input levels of capitalist firms and of co-ops were not the same but the differences were not stark. The possible exception was the use of raw materials, logs: the average input of logs among the capitalist firms was sixteen percent higher than the average among the co-ops. Given their similar output levels, this difference in raw material inputs implies that the average ratio of output to log inputs was higher for the co-ops than for the capitalist firms. This, in turn, was related to the estimated Cobb-Douglas production functions of the co-ops and capitalist firms: the estimated elasticity of output with respect to logs was larger in the production function for the capitalist firms than the corresponding production function elasticity fitted to the co-ops. Given that both types of firms faced the same prices for logs and for their plywood output, this difference in the elasticities of output with respect to logs in the production function means that the optimizing first-order condition for logs implies a higher ratio of output to raw materials for the co-ops than that for the capitalist firms. ${ }^{28}$

\footnotetext{
${ }^{27}$ Though equation (9) was estimated, we found that a more restrictive specification could not be rejected by conventional statistical criteria. This more restrictive specification replaced the estimated fixed time effects with a time trend (one trend for the co-ops and one for the capitalist firms) and replaced the firm-specific fixed effects with a co-op dummy. The results reported below refer to this specification when fitted by instrumental variables (using input and output prices and year and firm dummy variables as instrumental variables) to co-ops and to the unionized capitalist firms separately and to those mills producing only plywood.

${ }^{28}$ The argument here may be stated a little more formally. Let $\gamma^{j}$ be the elasticity of output with respect to log inputs in the production function estimated for firms of type $j$ where $j=\Pi$ for capitalist firms and $j=D$ for co-ops. For both types of firms, suppose the first-order condition for the optimal use of raw material logs, $G$, is $p(\partial X / \partial G)=r$ where $p$ is the price of output and $r$ is the per unit price of logs. Because $\gamma=(\partial X / \partial G)$. $(G / X)$, the first-order condition for logs may be written $(X / G)^{j} \cdot \gamma^{j}=r / p$ and, as $r / p$ is virtually the same for both types of firms, differences in $\gamma^{j}$ must be offset by differences in $(X / G)^{j}$. If $\gamma^{D}$ is lower than $\gamma^{I}$, then the first-order
} 
In terms of overall production efficiency, when the estimated production functions were simulated, at given inputs, the implied output of the coops averaged between six and fourteen percent more than that of conventional capitalist firms of approximately the same size. This does not mean that co-ops actually produce more than conventional firms and are prone to "overproduction”. How much they produce will depend on their goals and on input and output prices. It means that they are capable of producing a given output with fewer inputs than comparable capital-owned firms.

A major investigation into the production functions of capitalist firms and co-ops in French industry has recently been undertaken by Fakhfakh, Pérotin, and Gago (2010). They compile two data sets on annual observations on the inputs and value added of individual firms. In the earlier data set, there are 431 co-ops and 5,856 capitalist firms in seven industries over the years from 1987 to 1990 . In the later data set, there are 166 co-ops and 2,266 capitalist firms in four manufacturing industries over the years from 1989 to 1996. They specify augmented translog production functions to describe the patterns of inputs and value added across firms within each major industry where the parameters of the production functions for the co-ops are permitted to differ from those of the capitalist firms. ${ }^{29}$ For the 1987-90 data set, they allow for time-invariant firm-specific effects which they treat as random and they apply a generalized method-of-moments (GMM) estimator to the observations within each industry and for co-ops and capitalist firms separately. For the 1989-96

condition for logs requires $(X / G)^{D}$ to be higher than $(X / G)^{\Pi}$.

${ }^{29}$ The word "augmented" means that, in addition to labor and capital inputs, the equations include variables measuring the fraction of workers who are women and the fractions who are managers and supervisors. Also included is a variable measuring the firm's share of its product market. The authors write that this is designed to absorb the prices embedded in the dependent variable which is the logarithm of value added. 
data set, the translog specification is time-differenced (one year's observations subtracted from the subsequent year's observations) and the first differences of the inputs and the variables measuring the composition of the labor force are treated as endogenous using the lagged values of the variables expressed in levels as instrumental variables. This is estimated jointly with the equation specified in levels and using lagged differences in inputs as instrumental variables.

The authors report that tests of the null hypothesis of no difference between the production technologies of the co-ops and those of the capitalist firms are rejected "in all cases". They then simulate the outputs of the two production technologies at the same input levels. For the 1987-90 sample, in most industries, the co-ops' estimated technology yields higher output for given inputs than the technology estimated to capitalist firms. Results are less easily summarized for the 1989-96 sample and one wonders whether a problem of "weak" instruments lies behind "insignificant" differences. The authors conclude that, with respect to the production functions of co-ops and capitalist firms, "the two groups of firms are more similar than is usually thought". All in all, it is a thorough study and largely convincing.

The methods of Defourny, Lovell, and N'gbo's (1992) analysis of French cooperatives are different. They study production differences among coops, not between coops and capitalist firms. They posit a Cobb-Douglas production function ${ }^{30}$ and restrict the error term to take the form of a truncated normal to permit the interpretation of their fitted equation as a production frontier. Their estimating methods are treated as maintained hypotheses. They fit their equation to

\footnotetext{
30 The data sources for the research of Defourny et al. seem to be the same as those of Fakhfakh et al. (2010) and they share at least one industry in common (Printing), yet they report different results regarding their estimated production functions. Whereas Defourny et al. report that their estimation of the translog production function “....rarely works”, Fakhfakh et al. (2010) write, "the translog specification fits the data best...”.
} 
observations on 143 co-ops in four industries over two years. Again output is measured as value added. They allow for the effects on production of variations in nonmember workers to differ from those of variations in member workers. ${ }^{31}$ Also the effects on production of variations in externallyraised capital are allowed to differ from those of internally-provided capital.

In most of their estimates, the null hypothesis of no meaningful difference in the productivity of the two types of workers and the two types of capital cannot be rejected. They report important neutral efficiency differences across their co-ops. Explanations for these differences are not offered. They also conclude that conclusions about production efficiency that rest on production functions estimated with different assumptions about the nature of the errors and omitting indicators of membership among the workers may be "very misleading”. However, results from applying different estimating methods are not presented so the "misleading" conclusions are not demonstrated. Also, the production function estimates that omit the distinction between members and nonmembers appear little different from those that incorporate this distinction.

A similar study is that of Jones (2007) who uses annual observations on 26 worker co-ops and 51 conventional firms in the Italian construction industry over time in the 1980s. There are 374 firm-year observations in all, about one-third of which are on the co-ops. Over the observation period, the workers in the co-ops enjoyed only small additions to their basic compensation from the distribution of net revenues, a feature he attributes to the financially difficult period in Italian construction. The typical size of the conventional firms (measured by real value added or by capital input or by labor input) is noticeably larger (by some 20 to 60 percent) than that

\footnotetext{
${ }^{31}$ The fraction of all workers who are members varies across the four industries from an average of 57 \% in Public Works, 74 \% in Furniture, 77 \% in Printing, and 85 \% in Architecture. Some firms have no member workers.
} 
of the coops.

To describe the input-output patterns of these enterprises, Jones specifies a translog production function with fixed firm and fixed year effects and also adding terms that measure the extent of participation among the co-op workers. ${ }^{32}$ These participation indicators include variables in a given co-op in a given year measuring the proportion of members among the co-op’s work force, the average distributed profits per worker, and the average collectively-owned reserves per worker-member. The interest in whether such variables bear an association with output is understandable, but there is an "included variables problem" as well as the more familiar "omitted variables problem”: the more such performance-related indicators are included, the less likely is it that the fitted relation corresponds to a production function which is supposed to be restricted to inputs and output.

Moreover, in the equation that Jones estimates, the second-order terms in the translog function are constrained to have the same coefficients for coop and conventional firms so the notion of fitting two entirely different production technologies for the two classes of firms is not really applied. Furthermore, in one set of estimates, after first differencing the equation, the capital and labor inputs are treated as endogenous using lagged values of the endogenous variables as instrumental variables. The equation's error term is permitted to be heteroskedastic and serially correlated. In the first-difference instrumental variable estimates, almost 100 parameters are estimated, a somewhat courageous specification given 293 total observations.

Jones’ results are not easily summarized, but it seems that a consistent pattern

\footnotetext{
32 Jones writes, “translog production function estimates are preferred to Cobb Douglas estimates” though the reader is not shown this and the criteria determining "preference" are not described.
} 
favoring either the co-ops or the conventional firms is not apparent. This is not surprising given the attempt to use these data to explore many different hypotheses - not merely that one form of organization produces output more efficiently than the other but also that output is affected by the degree of financial participation, by the importance of membership in employment, by the size of each coop's reserves, by distributed profits, by the amount that members have loaned to their coop, in addition to unidentified firm-specific effects and time effects. A great deal is being asked of the data so that the absence of statistically significant differences from instrumental variable estimation is not surprising.

A general conclusion about the production efficiency of worker co-ops compared with conventional firms is difficult to draw. It would be remarkable if one organizational form dominated the other in every setting. There are enough instances in which co-ops seem no less efficient than capitalist firms that a presumption of co-ops' relative inefficiency is not warranted.

\section{Democratic Governance}

To this point, this paper's focus has been on the worker co-op as an organization for production and issues of employment governance have not been addressed. Of course, the questions about worker co-ops concern more than production and employment. As an organizational form, the worker co-op has appealed to some with democratic capitalist sympathies and to some with contrasting democratic socialist sympathies. To the former, the worker co-op is sometimes viewed as a mechanism by which capital ownership is extended to a wider section of the community: workers become capitalists! The interest of these capital owners is in protecting and furthering their 
investments which induce them to take an active part in the management of their firm. To some democratic socialists, the worker co-op is seen as the mechanism to give workers effective authority in guiding production and employment decisions. It is the extension of the political franchise to the economic realm. ${ }^{33}$ But how effective are workers in their capacity of making democratic decisions regarding the enterprise?

The type of governance problems that tend to characterize worker co-ops are illustrated by the recently published account of Oregon’s Burley Design Cooperative. Schoening (2010) describes how Burley was set up in the 1970s selling bicycle accessories such as panniers, cycling clothing, and trailers. Initially, all workers were co-op members and all co-op members were workers. Hourly pay was the same for all individuals and profits were distributed in proportion to each member's share of aggregate work hours. In the early years, all members engaged in decision-making in the manner of direct democracy.

As the firm grew in production and employment, non-member workers were taken on and, in the attempt to avoid the classic degeneration problem of members becoming a diminishing privileged minority, a rule was introduced that required membership to be offered to a hired worker who worked more than 1,500 hours in a year. However, some of these new members did not share the same values as the original members and the organization's distinctive participatory culture suffered. The quality of decision-making deteriorated and a hired general manager assumed more

${ }^{33}$ For robust statements in this vein, see Bowles and Gintis (1996), Dahl (1985), and Ellerman (1990). Ellerman writes, "Today's economic democrats are the new abolitionists trying to abolish the whole institution of renting people in favor of democratic self-management in the workplace" (1990, p. 210). Dahl writes, "If democracy is justified in governing the state, then it must also be justified in governing economic enterprises; and to say that it is not justified in governing economic enterprises is to imply that it is not justified in governing the state” (p. 111). 
responsibilities for determining issues. By 2006, to deal with continued losses, the remaining active members voted to turn their enterprise into a joint-stock company and then to sell it to a private investor who promptly cut the work force by one-half.

The experience of Burley Design Cooperative is a reminder that worker-owned firms require workers to assume critical costs of control and oversight and some workers resist taking on those costs. ${ }^{34}$ The collective interest is often difficult (costly) to determine and the member-workers may have to be sufficiently similar or to devote resources to become similar along many dimensions to arrive at agreeable policies. The relevance of the homogeneity of workers has been emphasized by Hansmann (1996) and by Abramitzky (2011) in their studies of American and Israeli communes. It figures also in Rothschild and Whitt’s (1986) investigation of cooperatives in California. They write, "Efforts to develop democratic workplaces often run into difficulties if they have a very heterogeneous work force” (p. 96).

Why is homogeneity important? Perhaps because the lubricant of trust is more easily engendered among like individuals. ${ }^{35}$ Or is it because consensus decisions are more easily reached and implemented? On the other hand, homogeneity “....narrows the membership base of the collective and it makes it less representative of the surrounding community” (Rothschild and Whitt (1986, p. 97)). Others have suggested that heterogeneous decision-makers make better decisions when faced with complex problems. In capitalist organizations, most shareholders are concerned simply with monetary returns and problems arising from heterogeneous preferences are avoided or so it is argued. However, owners have different time horizons and time preference rates and these

\footnotetext{
${ }^{34}$ Bowles and Gintis (1993) refer to these problems as constituting a “democratic capacities" constraint.

${ }^{35}$ See Jones and Kalmi (2009).
} 
sometimes result in opposing attitudes toward alternative income streams in capitalist enterprises.

A more systematic empirical analysis of these decision-making issues in the context of the organization of the firm would be valuable. A propitious direction for research may be the development of ingenious experiments that recreate the decision-making environment and that engineer the variables believed to affect behavior. For example, Mellizo, Carpenter, and Matthews (2011) devised an experiment that indicated that, when individuals were allowed to design their own payment mechanism, their subsequent work effort increased. The authors refer to the relevance of their results for workplace democracy.

\section{Conclusion}

Behind the claims that co-ops are more efficient work organizations are two distinct classes of argument. One is that the compensation mechanism - the sharing of net revenues - among member-workers provides incentives for greater or more effective work effort. Such a compensation system may also attract individuals who are less averse to work effort and who are attracted to the possibility of augmenting their income through superior work effort, a selection effect. A second class of argument concerns the participatory dimension of a worker co-op: an organization works more effectively when individuals are engaged in activities that they have helped to define and that they control. In principle, organizations that involve workers extensively in decision-making need not be organizations that use profit-sharing or revenue-sharing as a wage payment mechanism. In fact, firms that involve workers in decision-making within the organization tend also to be firms that use some sort of revenue-sharing mechanism to compensate their workers. 
The worker co-op is the limiting form of such a firm. It means that any productivity differences between capitalist firms and worker co-ops should distinguish among types of capitalist firms: if it is the profit-sharing element that matters most for productivity, then capitalist firms that use some sort of revenue-sharing mechanism for compensating their employees may be similar in productivity to the worker co-op; if it is the participation of workers in decision-making that matters most for productivity, then capitalist firms with employee-involvement programs or works councils may have similar productivity levels as worker co-ops. Or perhaps revenue-sharing payment schemes complement participatory mechanisms and it is the interaction of these two factors that matters most for productivity and there is little effect of one without the presence of the other. ${ }^{36}$ The literature on worker co-ops used to be characterized by theoretical speculation on how worker-owned enterprises behave and by particular case studies where generalization was avoided. The last twenty years or so has witnessed an increasing use of modern empirical methods applied to large numbers of observations to form empirical generalizations about the behavior of worker co-ops. As a result, much has been learned about worker-owned and worker-managed enterprises. As a generalization, it does not seem accurate to describe worker co-ops as technically less efficient operations than the capitalist firm. Co-ops do face governance problems arising perhaps from the differences among worker-owners, but when workers remain sufficiently homogeneous they may look forward to a long life.

There remain enduring claims about co-ops that have not been thoroughly examined and yet they are repeated over and over again when the topic of worker-owned firms arises. One

\footnotetext{
${ }^{36}$ See, for instance, Pendleton and Robinson (2010).
} 
old chestnut is that incentive problems inhibit co-ops from realizing a rapid rate of technological change. A second is that co-ops are ineffective in taking on outside unemployed workers when a local labor market is ailing. Third, in empirical research that evaluates the performance and evolution of the worker co-op, little attention has been directed to issues of financing. Yet, as noted above, some have suggested that the co-op fares better and resists degeneration when it relies on external financing. It would be heartening to think that the next twenty years would bring empirical research to bear on these neglected issues. 


\section{REFERENCES}

Abramitzky, Ran, “Lessons from the Kibbutz on the Equality-Incentives Trade-Off”, $\underline{\text { Journal of }}$ Economic Perspectives, 24(4), Fall 2010, 1-24

Abramitzky, Ran, “On the (Lack of) Stability of Communes: An Economic Perspective”, in Rachel McCleary, ed., Oxford Handbook of the Economics of Religion, Oxford University Press, Oxford, 2011, Chapter 9, 169-189

Arando, Saioa, Fred Freundlich, Monica Gago, Derek C. Jones, and Takao Kato, “Assessing Mondragon: Stability and Managed Change in the Face of Globalization”, IZA DP No. 5711, May 2011.

Ben-Ner, Avner, “The Life Cycle of Worker-Owned Firms in Market Economies: A Theoretical Analysis”, Journal of Economic Behavior and Organization , 10, 1988, 287-313.

Bloom, Nicholas, and John Van Reenan, "Human Resource Management and Productivity”, National Bureau of Economic Research Working Paper 16019, May 2010.

Blundell, Richard, and Steve Bond, “GMM Estimation with Persistent Panel Data: An Application to Production Functions”, Econometric Reviews 19(3), 2000, 321-40. 
Bonin, John P., Derek C. Jones, and Louis Putterman, "Theoretical and Empirical Studies of Producer Cooperatives: Will Ever the Twain Meet?”, Journal of Economic Literature, 31(3), September 1993, 1290-1320.

Bowles, Samuel, and Herbert Gintis, "A Political and Economic Case for the Democratic Enterprise”, Economics and Philosophy, 9 (1), 1993, 75-100.

Bowles, Samuel, and Herbert Gintis, “'”s the Demand for Workplace Democracy Redundant in a Liberal Economy?”, in Ugo Paganao and Robert Rowthorn, eds., Democracy and Efficiency in the Economic Enterprise , Routledge, London, 1996, 64-81.

Burdin, Gabriel, "Does Workers’ Control Affect Firm Survival? Evidence from Uruguay”, unpublished manuscript, 2012.

Burdín, Gabriel, and Andrés Dean, "New Evidence on Wages and Employment in Worker Cooperatives Compared with Capitalist Firms”, Journal of Comparative Economics 37(4) , December 2009, 517-33.

Cable, John, and Nicholas Wilson, "Profit-Sharing and Productivity: An Analysis of U.K. Engineering Firms”, The Economic Journal , 99 (396), June 1989, 366-75. 
Cornforth, Chris, "Patterns of Cooperative Management: Beyond the Degeneration Thesis", Economic and Industrial Democracy, vol. 16, 1995, 487-523.

Craig, Ben, and John Pencavel, "Participation and Productivity: A Comparison of Worker Cooperatives and Conventional Firms in the Plywood Industry”, Brookings Papers on Economic Activity Microeconomics , 1995, 121-60.

Dahl, Henry G., Jr., “Worker-Owned Plywood Companies in the State of Washington”, The First National Bank of Everett, Everett, Washington, mimeograph, April 1957.

Dahl, Robert, Preface to Economic Democracy, University of California Press, 1985.

Defourny, Jacques, C.A.Knox Lovell, and Aké G.M.N’gbo , "Variation in Productive Efficiency in French Workers' Cooperatives”, Journal of Productivity Analysis, Vol. 3, Nos. 1-2, 1992, 99-113.

Dow, Gregory K., Governing the Firm: Workers' Control in Theory and Practice, Cambridge University Press, Cambridge, 2003.

Dow, Gregory, and Louis Putterman, "Why Capital (Usually) Hires labor: An Assessment of Proposed Explanations” in Margaret Blair and Mark J. Roe, eds., Employees and Corporate Governance, Brookings, 1999, pp. 17-57. 
Ellerman, David P., The Democratic Worker-Owned Firm, Unwin Hyman, Boston, 1990.

Estrin, Saul, "Long-Run Supply Responses under Self-Management”, Journal of Comparative Economics 6 , December 1982, 363-78.

Fakhfakh, Fathi, Virginie Pérotin, and Mónica Gago, "Productivity, Capital and Labor in LaborManaged and Conventional Firms”, manuscript, April 2010.

Hansmann, Henry, The Ownership of Enterprise, Harvard University Press, Cambridge, Mass., 1996.

Hoch, Irving, "Estimation of Production Function Parameters Combining Time-Series and CrossSection Data”, Econometrica, 30(1), January 1962, 34-53.

Ireland, Norman J., and Peter J. Law, The Economics of Labor-Managed Enterprises, St. Martin’s Press, New York, 1982.

Jones, Derek C., “The Productive Efficiency of Italian Producer Cooperatives: Evidence from Conventional and Cooperative Firms", Advances in the Economic Analysis of Participatory and Labour Managed Firms, vol. 10, 2007, 3-28. 
Jones, Derek C., and Panu Kalmi, “Trust, Inequality, and the Size of Co-operative Sector: CrossCountry Evidence”, Annals of Public and Co-operative Economy , 80(2), June 2009, 165-95.

Jones, Derek C., and Takao Kato, “The Productivity Effects of Employee Stock-Ownership Plans and Bonuses: Evidence from Japanese Panel Data”, American Economic Review, 85(3), June 1995, 391-414.

Kruse, Douglas L., Richard B. Freeman, and Joseph R. Blasi, eds., Shared Capitalism at Work, University of Chicago Press, Chicago, 2010.

Lamoreaux, Naomi, “Partnerships, Corporations, and the Theory of the Firm”, American Economic Review, Papers \& Proceedings, 88(2), May 1998, 66-71.

Levin, Jonathan, and Steven Tadelis, "Profit Sharing and the Role of Professional Partnerships", Quarterly Journal of Economics, 120(1), February 2005, 131-71.

MaCurdy, “A Practitioner’s Approach to Estimating Intertemporal Relationships using Longitudinal Data: Lessons from Applications in Wage Dynamics”, Chapter 62 of Handbook of Econometrics, Vol. 6A, ed. by James Heckman and Edward Leamer, Elsevier B.V., Amsterdam, 2007, 4057-4167.

Mattey, Joe P., The Timber Bubble That Burst, New York: Oxford University Press, 1990. 
Mellizo, Philip, Jeffrey Carpenter, and Peter Hans Matthews, "Workplace Democracy in the Lab”, IZA Discussion Paper No. 5460, January 2011

Mundlak, Yair, "Estimation of Production and Behavioral Functions from a Combination of CrossSection and Time-Series Data”, in Measurement in Economics: Studies in Mathematical Economics and Econometrics in Memory of Yehuda Grunfeld, Stanford Univ Press, Stanford, California 1963, $138-66$.

Nerlove, Marc, “A Note on Error Components Models”, Econometrica, 39, 1971, 359-82.

Pencavel, John, and Ben Craig, “The Empirical Performance of Orthodox Models of the Firm : Conventional Firms and Worker Cooperatives”, Journal of Political Economy , 102 (4), August 1994, 718-44.

Pencavel, John, Luigi Pistaferri, and Fabiano Schivardi, "Wages, Employment, and Capital in Capitalist and Worker-Owned Firms”, Industrial and Labor Relations Review, 60(1), October 2006, 23-44.

Pendleton, Andrew, and Andrew Robinson, "Employee Stock Ownership, Investment, and Productivity: An Interaction-Based Approach”, Industrial and Labor Relations Review, 64(1), October 2010, 3-29. 
Pérotin, Virginie, and Andrew Robinson, "Employee Participation in Profit and Ownership: A Review of the Issues and Evidence”, European Parliament Working Paper SOCI 109 EN, 2003.

Potter, Beatrice, The Co-operative Movement of Great Britain, Swan Sonnenschein, London, 1891

Rampell, Catherine, “At Well-Paying Law Firms, a Low-Paid Corner”, New York Times, 23 May 2011

Rothschild, Joyce, and J. Allen Whitt, The Cooperative Workplace: Potentials and Dilemmas of Organizational Democracy and Participation, Cambridge University Press, Cambridge, 1986.

Satt, Ehud, "Introducing Differential Wage Rates in the Kibbutz Economy: Is It the End of the Kibbutz? Theory and New Data”, from Sonja Novkovic and Vania Sena, eds., Cooperative Firms in Global Markets: Incidence, Viability and Economic Performance, Vol. 10 of Advances in the Economic Analysis of Participatory and Labor Managed Firms, JAI Press Inc., Bingley, U.K., 2007, 79-107

Schoening, Joel, “The Rise and Fall of Burley Design Cooperative”, Oregon Historical Quarterly, 31(3), Fall 2010, 312-41. 
Vanek, Jaroslav, "Some Fundamental Considerations on Financing and the Form of Ownership under Labor Management” in his The Labor-Managed Economy, Cornell University Press, Ithaca, 1977, 171-85

Ward, Ben, “The Firm in Illyria: Market Syndicalism”, American Economic Review, 48(4), September 1958, 566-89.

Webb, Sidney, and Beatrice Webb, The Consumers’ Co-operative Movement, Longmans, London, 1921 